\title{
Seleksi Atribut Menggunakan Information Gain Untuk Clustering Penduduk Miskin Dengan Validity Index Xie Beni
}

\author{
Femi Dwi Astuti \\ Program Studi Teknik Informatika \\ STMIK AKAKOM \\ femi@akakom.ac.id
}

\begin{abstract}
Abstrak - Di wilayah Kecamatan Bantul, seorang warga disebut sebagai keluarga miskin berdasarkan beberapa aspek seperti aspek pangan, sandang, papan, penghasilan, kesehatan, pendidikan, kekayaan, air bersih, listrik maupun jumlah jiwa. Aspek-aspek tersebut akan digunakan sebagai atribut dalam proses clustering. Masing-masing atribut memiliki nilai yang akan diolah. Penelitian ini dikerjakan menggunakan seleksi atribut information gain sebelum proses clustering untuk melihat atribut mana yang sebenarnya berpengaruh dan tidak, sehingga hanya atribut yang berpengaruh saja yang akan digunakan, metode $F u z z y C$ Means untuk clustering penduduk miskin dan Xie Beni untuk menentukan jumlah klaster terbaik. Hasil penelitian menunjukkan penggunaan information gain dengan threshold 0.0001 untuk clustering dengan menghilangkan atribut penghasilan memiliki hasil cluster yang sama dengan menggunakan atribut penghasilan. Pengujian terhadap 23, 500, 1000 dan 1313 untuk jumlah cluster 2, 3, 4, 5, 6 dan 7 menunjukkan bahwa nilai dari Xie-Beni Index terkecil adalah 5 dengan nilai 0,1343 , sehingga cluster yang paling optimal adalah 5.

Kata Kunci : Clustering, Information Gain, Kemiskinan, Fuzzy C-Means, Xie-Beni
\end{abstract}

\section{PENDAHULUAN}

Masalah utama dalam proses discovering knowledge dari data penduduk miskin adalah mengidentifikasi atribut yang tepat untuk proses clustering. Di wilayah Kecamatan Bantul, seorang warga disebut sebagai keluarga miskin berdasarkan beberapa aspek seperti aspek pangan, sandang, papan, penghasilan, kesehatan, pendidikan, kekayaan, air bersih, listrik maupun jumlah jiwa. Aspek-aspek tersebut akan digunakan sebagai atribut dalam proses clustering. Masingmasing atribut memiliki nilai yang akan diolah. Penduduk miskin di Kecamatan Bantul sebanyak 1313 keluarga. Keluarga-keluarga tersebut memiliki karakteristik yang berbeda-beda. Saat ini, penduduk di Kecamatan Bantul dikatakan sangat miskin apabila jumlah nilai dari 11 atribut tersebut tinggi, dengan cara demikian, pemberian bantuan menjadi tidak tepat sasaran karena belum pasti dari aspek mana keluarga tersebut kekurangan. Atribut-atribut yang banyak dan sebenarnya tidak berpengaruh dapat mengurangi kinerja algoritma clustering, sehingga perlu dilakukan seleksi atribut untuk mengetahui atribut yang sebenarnya berpengaruh dan yang tidak berpengaruh.

Penggunaan seleksi atribut memiliki hasil akurasi yang lebih baik jika dibandingkan dengan klasifikasi tanpa melalui seleksi fitur [1]. Seleksi fitur yang menunjukkan akurasi tertinggi yaitu Information Gain [2]. "Indeks Xie Beni digunakan untuk pengelompokkan karena memiliki ketepatan dan kehandalan yang tinggi untuk digunakan sebagai kriteria dalam menentukan jumlah kelompok yang optimum" [3]. Pemilihan cluster optimum pada hasil clustering untuk kasus pengelompokkan kabupaten/kota diprovinsi Jawa Tengah berdasarkan variabel pembentuk indeks pembangunan manusia pernah diteliti oleh Purnamasai [4].

Upaya-upaya untuk membantu program pengentasan kemiskinan di daerah Bantul pernah dilakukan melalui beberapa penelitian. Penentuan indikator yang berperan pada identifikasi kemiskinan menggunakan data mining pernah dilakukan dan hasilnya menunjukkan 8 indikator dari 11 indikator yang berperan [5]. Penelitian serupa dilakukan untuk klasifikasi keluarga miskin menggunakan Analytical Hierarchy Process (AHP) [6].

Teknik seleksi atribut dilakukan untuk mengurangi fitur yang tidak relevan dan mengurangi dimensi atribut pada data. Tujuan penelitan ini adalah untuk mengidentifikasi atribut yang paling berpengaruh maupun yang tidak berpengaruh terhadap proses clustering penduduk miskin dengan mengimplementasikan teknik seleksi atribut Information Gain. Analisis information gain attribut evaluation pernah dilakukan untuk klasifikasi serangan intrusi yang hasilnya menyatakan information gain tidak mampu secara signfikan meningkatkan performansi akurasi, deteksi dan false positive algoritma Naive Bayes [7]. Selain bertujuan untuk menyeleksi fitur/atribut, tujuan lain dari penelitian ini yaitu mencari jumlah cluster paling optimal menggunakan validasi index Xie Beni. Penelitian ini diterapkan pada algoritma clustering Fuzzy C-Means. Pengujian akan dilakukan untuk membandingkan hasil sebelum seleksi atribut dan sesudah seleksi atribut.

Keakuratan hasil cluster perlu diperhatikan sehingga hasil pengelompokkan menjadilebih optimal. Pada penelitian 
ini, evaluasi tingkat keakuratan klaster menggunakan Algoritma Xie-Beni Index. Algoritma ini merupakan algoritma evaluasi keakuratan klaster yang paling banyak digunakan. Algoritma ini melibatkan kedua matriks U dan kumpulan data.

\section{METODOLOGI PENELITIAN}

Metode-metode yang digunakan dalam penelitian ini diantaranya adalah information gain untuk seleksi atribut, fuzzy c-means untuk clustering penduduk miskin dan validity index xie beni untuk menentukan jumlah cluster terbaik.

\section{A. Information Gain}

Information Gain dari suatu atribut diperoleh dari nilai entropy sebelum pemisahan dikurangi dengan nilai entropy setelah pemisahan. atribut yang tidak relevan akan menurunkan performa machine learning. Sedangkan atribut yang redundan akan membuat machine learning bekerja lebih lama [8]. Seleksi fitur menggunakan information gain dilakukan dengan cara menghitung nilai gain setiap fitur. Ada tiga tahapan dalam pemilihan fitur menggunakan Information Gain diantaranya adalah sebagai berikut :

1. Hitung nilai gain informasi untuk setiap atribut dalam dataset asli

2. Buang semua atribut yang tidak memenuhi kriteria yang ditentukan

3. Dataset direvisi

Pengukuran atribut ini dipelopori oleh Claude Shannon pada teori informasi, dituliskan dengan persamaan (1) :

$$
\operatorname{Inf} o(D)=-\sum_{i=1}^{m} p_{i} \log _{2} p_{i}
$$

Keterangan :

$$
\begin{array}{ll}
D & =\text { himpunan kasus } \\
m & =\text { jumlah partisi } D \\
p_{i} & =\text { Proporsi dari } D_{i} \text { terhadap } D
\end{array}
$$

Dalam hal ini $p_{i}$ adalah probabilitas sebuah tuple pada $D$ masuk ke kelas $C_{i}$ dan diestimasi dengan $\left|C_{i}, D\right| /|D|$. Fungsi diambil berbasis 2 karena informasi dikodekan berbasis bit. Selanjutnya mencari nilai entropy setelah pemisahan dengan persamaan (2) :

$$
\operatorname{Info}_{A}(D)=-\sum_{j=1}^{v} \frac{\left|D_{j}\right|}{|D|} x I\left(D_{j}\right)
$$

Keterangan :

$$
\begin{array}{ll}
D & =\text { Himpunan kasus } \\
A & =\text { Atribut } \\
v & =\text { jumlah partisi atribut } A \\
\left|D_{j}\right| & =\text { jumlah kasus pada partisi ke } j \\
\|D\| & =\text { jumlah kasus dalam } D \\
I\left(D_{j}\right) & =\text { total entropy dalam partisi }
\end{array}
$$

Untuk mencari nilai Information Gain atribut A diperoleh dengan persamaan (3):

$$
\operatorname{Gain}(A)=I(D)-I(A)
$$

Keterangan :

$\operatorname{Gain}(A)=$ information gain atribut $A$

$\begin{array}{ll}I(D) & =\text { total entropy } \\ I(A) & =\text { entropy } A\end{array}$

Dengan penjelasan lain, Gain(A)adalah reduksi yang diharapkan di dalam entropi yang disebabkan oleh pengenalan nilai atribut dari A. Atribut yang memiliki nilai information gain terbesar dipilih sebagai uji atribut untuk himpunan S. Selanjutnya suatu simpul dibuat dan diberi label dengan label atribut tersebut, dan cabang-cabang dibuat untuk masing-masing nilai dari atribut.

\section{B. Validity Index Xie Beni}

Sesuai dengan namanya Indeks XB ditemukan oleh Xie dan Beni yang pertama kali dikemukakan pada tahun 1991. Validitas dalam HCM ditentukan oleh banyak kelompok optimum melalui perhitungan Indeks validitas. Proses validasi index dengan Xie Beni membandingkan rata-rata pusat cluster akhir dengan data validasi yang diperoleh dari data penduduk miskin, Rumus proses validasi menggunakan Xie-Beni index dapat dilihat pada persamaan 4.

$$
\mathrm{XB}(c)=\frac{\sum_{k=1}^{n} \sum_{i=1}^{c}\left(\left[\sum_{a=1}^{p}\left(X_{k a}-V_{i a}\right)^{2}\right]\left(\mu_{i k}\right)\right)}{n \cdot \min _{i, j}\left\|V_{i}, V_{j}\right\|^{2}}
$$

Formula ini dapat digunakan untuk metode hard ataupun fuzzy partition seperti K-means cluster maupun FCM. Kriterianya banyak kelompok optimum diberikan oleh nilai XB yang minimum pada lembah pertama. Dengan c menyatakan banyak cluster, $\mu_{\mathrm{ik}}$ adalah tingkat keanggotaan, $\left[\sum_{a=1}^{p}\left(X_{k a}-V_{i a}\right)^{2}\right]$ adalah jarak observasi dengan pusat cluster, $V_{i}$ adalah pusat cluster, $n$ merupakan banyak objek yang akan dikelompokkan, $\min _{i, j}\left\|V_{i}, V_{j}\right\|^{2}$ menyatakan jarak minimum antara pusat cluster $V_{i}$ dan $V_{j}$. Kriteria banyak cluster optimum diberikan oleh indeks XB yang minimum. Indeks XB memiliki ketepatan dan keandalan yang tinggi baik untuk memberikan banyak kelompok optimum pada metode hard partition seperti $K$-means cluster maupun pada FCM [9].

\section{Kemiskinan}

"Kemiskinan adalah suatu keadaan seseorang atau keluarga yang serba kekurangan”. Indikator yang digunakan untuk menentukan keluarga miskin di Kabupaten Bantul dapat dilihat pada Tabel 1.

Tabel 1. Indikator Kemiskinan BKKBN

\begin{tabular}{llc}
\hline \multicolumn{1}{c}{ Aspek } & \multicolumn{1}{c}{ Keterangan } & Skor \\
\hline Pangan & $\begin{array}{l}\text { Seluruh anggota keluarga tidak } \\
\text { mampu makan dengan layak atau }\end{array}$ & 12 \\
& $\begin{array}{l}\text { senilai Rp. 1.500,- minimal 2 kali } \\
\text { dalam sehari }\end{array}$ & \\
\hline Sandang & $\begin{array}{l}\text { Lebih dari sebagian anggota } \\
\text { keluarga tidak memiliki pakaian } \\
\text { pantas pakai minimal 6 stel }\end{array}$ & \\
\hline
\end{tabular}




\begin{tabular}{|c|c|c|}
\hline Aspek & Keterangan & Skor \\
\hline Papan & $\begin{array}{l}\text { Lebih dari } 50 \% \text { Tempat tinggal/ } \\
\text { rumah berlantai tanah/ berdinding } \\
\text { bambu/ berataprumbia }\end{array}$ & 9 \\
\hline Penghasilan & $\begin{array}{l}\text { Jumlah penghasilan yang diterima } \\
\text { seluruh anggota keluarga yang } \\
\text { berusia } 16 \text { tahun keatas < Rp. } \\
993.484\end{array}$ & 35 \\
\hline Kesehatan & $\begin{array}{l}\text { Bila ada anggota keluarga yang } \\
\text { sakit tidak mampu berobat ke } \\
\text { fasilitas kesehatan dasar }\end{array}$ & 6 \\
\hline Pendidikan & $\begin{array}{lr}\text { Keluarga tidak } & \text { mampu } \\
\text { menyekolahkan anak } & \text { yang } \\
\text { berumur } 7-15 \text { tahun } & \\
\end{array}$ & 6 \\
\hline Kekayaan 1 & $\begin{array}{lcr}\text { Jumlah } & \text { kekayaan/aset } & \text { milik } \\
\text { keluarga } & \text { kurang } & \text { dari } \\
\text { Rp.2.500.000,- } & & \\
\end{array}$ & 5 \\
\hline Kekayaan 2 & $\begin{array}{l}\text { Tanah bangunan yang ditempati } \\
\text { bukan milik sendiri }\end{array}$ & 6 \\
\hline Air Bersih & $\begin{array}{l}\text { Tidak menggunakan air bersih } \\
\text { untuk keperluan makan, minum \& } \\
\text { MCK }\end{array}$ & 4 \\
\hline Listrik & $\begin{array}{l}\text { Tidak menggunakan listrik untuk } \\
\text { keperluan rumah tangga }\end{array}$ & 3 \\
\hline $\begin{array}{l}\text { Jumlah } \\
\text { Jiwa }\end{array}$ & $\begin{array}{l}\text { Jiwa dalam KK ( termasuk kepala } \\
\text { keluarga ) } 5 \text { jiwa atau lebih }\end{array}$ & 5 \\
\hline
\end{tabular}

\section{Gambaran Umum Penelitian}

Gambaran umum penelitian dapat dilihat dari Gambar 1. Berdasarkan Gambar 1 dapat dilihat, proses penelitian dimulai dengan mengumpulkan data penduduk miskin di Kecamatan Bantul. Data yang sudah diperoleh perlu diseleksi terlebih dahulu untuk melihat atribut-atribut yang paling berpengaruh dan yang sebenarnya tidak berpengaruh. proses ini dilakukan dengan menggunakan information gain. Selanjutnya dataset hasil seleksi atribut disimpan kedalam database untuk kemudian dilakukan clustering menggunakan metode FCM. hasil clustering FCM selanjutnya dievaluasi untuk melihat jumlah cluster optimal menggunakan Xie Beni. User selain dapat melihat informasi hasil clustering FCM juga dapat melihat hasil perhitungan Xie Beni.

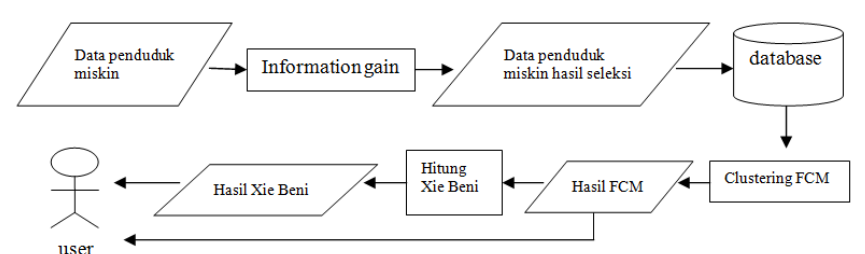

Gambar 1. Gambaran Umum Penelitian

\section{HASIL DAN PEMBAHASAN}

Data yang digunakan adalah data penduduk miskin Kecamatan Bantul yang berjumlah 1313 keluarga miskin dari 5 Desa dan 41 Dukuh. Sebelum dilakukan implementasi sistem, tahap yang dilalui pada penelitian ini yaitu pre-

prosessing untuk mengetahui atribut yang paling berpengaruh terhadap proses pengelompokkan penduduk miskin. Tujuan seleksi atribut adalah untuk mengidentifikasi beberapa atribut dalam kumpulan data yang sama pentingnya, dan membuang semua atribut lain seperti informasi yang tidak relevan. Langkah untuk seleksi atribut merupakan langkah pre-processing yaitu dengan menghilangkan atribut dari data yang tidak relevan sebelum digunakan pada algoritma data mining. Nilai information gain terbesar pada atribut suatu data menunjukkan bahwa atribut tersebut adalah atribut yang paling informatif, yang artinya paling relevan terhadap kelas targetnya. Semakin besar nilai information gain yang diperoleh pada suatu atribut, maka semakin besar pula pengaruhnya terhadap proses pengelompokkan keluarga miskin. Berdasarkan persamaan yang sudah dijelaskan sebelumnya, total entropy yang diperoleh berdasarkan data sebesar 0,3347 sedangkan nilai entropy dari masing-masing atribut dapat dilihat pada tabel 2.

Tabel 2. Nilai Entropy

\begin{tabular}{ccc}
\hline No & Atribut & Entropy \\
\hline 1 & Pangan & 0,269810836 \\
\hline 2 & Sandang & 0,325991347 \\
\hline 3 & Papan & 0,313190748 \\
\hline 4 & Penghasilan & 0,334658436 \\
\hline 5 & Kesehatan & 0,304213372 \\
\hline 6 & Pendidikan & 0,33223421 \\
\hline 7 & Kekayaan 1 & 0,326143384 \\
\hline 8 & Kekayaan 2 & 0,329702732 \\
\hline 9 & Air bersih & 0,306034021 \\
\hline 10 & Listrik & 0,320632292 \\
\hline 11 & Jumlah Jiwa & 0,334154932 \\
\hline
\end{tabular}

Berdasarkan hasil total entropy dan entropy dari masingmasing atribut, selanjutnya dihitung nilai gain dari masingmasing atribut dengan cara mengurangkan total entropy dengan entropy dari masing-masing atribut. Hasil perhitungan information gain pada setiap atribut untuk penelitian ini dapat dilihat pada tabel 3 .

Tabel 3. Nilai Information Gain

\begin{tabular}{clr}
\hline No & Atribut & \multicolumn{1}{c}{$\begin{array}{c}\text { Information } \\
\text { Gain }\end{array}$} \\
\hline 1 & Pangan & 0,064906055 \\
\hline 2 & Sandang & 0,008725544 \\
\hline 3 & Papan & 0,021526143 \\
\hline 4 & Penghasilan & 0,00006 \\
\hline 5 & Kesehatan & 0,030503519 \\
\hline 6 & Pendidikan & 0,002482681 \\
\hline 7 & Kekayaan 1 & 0,008573507 \\
\hline 8 & Kekayaan 2 & 0,005014159 \\
\hline 9 & Air bersih & 0,02868287 \\
\hline 10 & Listrik & 0,014084599 \\
\hline 11 & Jumlah Jiwa & 0,00056 \\
\hline
\end{tabular}


Berdasarkan hasil perhitungan seleksi atribut menggunakan Information Gain yang ada pada Tabel 3. dapat dilihat bahwa nilai Information Gain yang terendah adalah atribut penghasilan dengan nilai 0,00006 dan nilai Information Gain tertinggi adalah atribut pangan dengan nilai Information Gain sebesar 0,064906055. Nilai untuk atribut sandang dan kekayaan 1 (kekayaan selain tanah) mempunyai nilai information gain yang hampir sama, nilai atribut sandang sebesar 0,008725544 , sedangkan nilai pada atribut kekayaan 1 sebesar 0,008573507. Nilai-nilai information gain yang hampir sama juga ada pada atribut air bersih dan atribut papan. Nilai untuk atribut papan sebesar 0,021526143 dan atribut air bersih sebesar 0,02868287. Atribut kesehatan dan listrik memiliki nilai gain yang hampir sama dengan atribut papan dan air bersih yaitu sebesar 0,030503519 dan 0,014084599 . Nilai atribut pendidikan dan kekayaan 2 berturut-turut sebesar 0,002482681 dan 0,005014159. Atribut jumlah jiwa juga memiliki nilai information gain yang rendah sebesar 0,00056.

Dari hasil tersebut dapat disimpulkan bahwa atribut yang paling berpengaruh dalam penentuan kelompok keluarga miskin adalah atribut pangan, dan atribut yang paling tidak berpengaruh adalah atribut penghasilan. Hal ini bertolak belakang dengan kondisi sesungguhnya. Pada kondisi sesungguhnya, data atribut penghasilan memiliki skor nilai yang paling tinggi diantara atribut yang lain yaitu sebesar 35 . Secara umum, atribut penghasilan merupakan atribut paling berpengaruh terhadap penentu keluarga miskin, akan tetapi berdasarkan information gain, justru atribut penghasilan memiliki nilai gain terendah. Setalah dianalisa, hal ini disebabkan karena data penduduk yang dipakai, semua penduduk mempunyai nilai 35 (Jumlah penghasilan yang diterima seluruh anggota keluarga yang berusia 16 tahun keatas < Rp. 993.484). Hasil dari Information Gain dapat digunakan sebagai bahan pertimbangan pihak BKKBN maupun pihak pemerintah untuk mengkaji ulang terkait ketentuan besaran penghasilan yang digunakan sebagai dasar penentu keluarga miskin. Setelah diketahui nilai gain dari setiap atributnya langkah selanjutnya adalah menentukan nilai ambang (Threshold), dan dalam penelitian ini nilai ambang yang diambil adalah 0,00001 sehingga atribut yang terpilih adalah semua atribut yang ada. Pada penelitian ini akan dicoba dibandingkan proses pengelompokkan penduduk miskin dengan menggunakan 11 atribut dan 10 atribut (dengan menghilangkan atribut penghasilan).

\section{A. Perbandingan hasil FCM dengan $I G$ dan tanpa $I G$}

Pengujian ini akan membandingkan hasil FCM dengan menggunakan seleksi atribut Information Gain dan tanpa menggunakan seleksi atribut Information Gain. Atribut yang akan digunakan dalam penelitian ini sebanyak 11 atribut (pangan, sandang, papan, penghasilan, kesehatan, pendidikan, kekayaan 1, kekayaan 2, listrik, air bersih dan jumlah jiwa). Hasil penggunaan 11 atribut tersebut akan dibandingkan dengan hasil clustering dengan seleksi atribut information gain. Nilai threshold yang digunakan pada information gain yaitu 0,0001. Dengan nilai threshold tersebut, atribut penghasilan akan dihilangkan sehingga atribut yang digunakan sebanyak 10 atribut (pangan, sandang, papan, kesehatan, pendidikan, kekayaan 1, kekayaan 2, listrik, air bersih dan jumlah jiwa). Data uji yang digunakan dalam penelitian ini sebanyak 1313 data penduduk.

Berdasarkan tabel 4 dapat dilihat bahwa dengan menggunakan information gain dan tanpa menggunakan information gain memiliki hasil cluster yang sama. Dengan menggunakan Information Gain berarti menghilangkan atribut penghasilan. Setelah atribut penghasilan dihilangkan, diperoleh data hasil cluster. Hasil cluster tanpa atribut penghasilan dibandingkan dengan yang menggunakan atribut penghasilan. Hasil cluster tanpa menggunakan atribut penghasilan diperoleh data dalam cluster pertama sebanyak 259 keluarga, dengan anggota penduduk nomor $\{4,6,13$, $14,20,21,28,36,38,39,44,49, \ldots\}$. Cluster kedua sebanyak 297 memiliki anggota penduduk nomor $\{9,10,16$, $18,29,33,37,41,43,50,57, \ldots\}$. Cluster ketiga sebanyak 504 , memiliki anggota penduduk nomor $\{12,15,17,19,25$, 26, 32, 42, 47, 56, 67,..\} dan Cluster keempat sebanyak 253 , memiliki anggota penduduk nomor $\{1,2,3,5,7,8,11$, $22,23,24,27,30,31, \ldots\}$.

Tabel 4. Uji Perbandingan Dengan IG dan Tanpa IG

\begin{tabular}{|c|c|c|c|c|}
\hline \multirow{2}{*}{$\begin{array}{c}\text { Clust } \\
\text { er }\end{array}$} & \multicolumn{2}{|c|}{$\begin{array}{c}\text { Dengan IG } \\
\text { (menghilangkan } \\
\text { atribut penghasilan) }\end{array}$} & \multicolumn{2}{|c|}{ Tanpa IG } \\
\hline & Jmlh & $\begin{array}{l}\text { Data dalam } \\
\text { cluster }\end{array}$ & Jmlh & $\begin{array}{c}\text { Data dalam } \\
\text { cluster }\end{array}$ \\
\hline $\mathrm{C} 1$ & 259 & $\begin{array}{l}\{4,6,13,14,20 \\
, 21,28,36,38 \\
39,44,49, \ldots\}\end{array}$ & 504 & $\begin{array}{l}\{12,15,17,19,2 \\
5,26,32,42,47 \\
56,67, \ldots\}\end{array}$ \\
\hline $\mathrm{C} 2$ & 297 & $\begin{array}{l}\{9,10,16,18,2 \\
9,33,37,41,43 \\
, 50,57, \ldots\}\end{array}$ & 297 & $\begin{array}{l}\{9,10,16,18,29 \\
, 33,37,41,43,5 \\
0,57, \ldots\}\end{array}$ \\
\hline C3 & 504 & $\begin{array}{l}\{12,15,17,19 \\
25,26,32,42,4 \\
7,56,67, \ldots\}\end{array}$ & 259 & $\begin{array}{l}\{4,6,13,14,20, \\
21,28,36,38,39 \\
, 44,49, \ldots\}\end{array}$ \\
\hline $\mathrm{C} 4$ & 253 & $\begin{array}{l}\{1,2,3,5,7,8,1 \\
1,22,23,24,27 \\
, 30,31, \ldots\}\end{array}$ & 253 & $\begin{array}{l}\{1,2,3,5,7,8,11 \\
, 22,23,24,27,3 \\
0,31, \ldots\}\end{array}$ \\
\hline
\end{tabular}

Hasil cluster menggunakan atribut penghasilan diperoleh data dalam cluster pertama sebanyak 504 keluarga, dengan anggota penduduk nomor $\{12,15,17,19,25,26,32,42,47$, $56,67, \ldots\}$. Cluster kedua sebanyak 297 memiliki anggota penduduk nomor $\{9,10,16,18,29,33,37,41,43,50$, $57, \ldots\}$. Cluster ketiga sebanyak 259, memiliki anggota penduduk nomor $\{4,6,13,14,20,21,28,36,38,39,44$, $49, \ldots\}$ dan Cluster keempat sebanyak 253, memiliki anggota penduduk nomor $\{1,2,3,5,7,8,11,22,23,24,27,30$, $31, \ldots\}$.

Berdasarkan hasil tersebut, dapat dilihat bahwa dalam satu cluster, memiliki anggota kelompok yang sama. Sebagai contoh, dengan menggunakan atribut penghasilan (tanpa information gain) penduduk nomor 12 menjadi satu cluster dengan penduduk nomor 15, 17, 19, 25, 26, 32, 42, 47, 56, 67 dan lainnya. Dengan menggunakan information gain 
(tanpa atribut penghasilan), penduduk nomor 12 juga menjadi satu cluster dengan penduduk nomor 15, 17, 19, 25, 26, 32, 42, 47, 56, 67 dan lainnya. Kondisi tersebut juga berlaku untuk cluster-cluster yang lain. Dari pembahasan tersebut dapat disimpulkan bahwa sebenarnya atribut penghasilan tidak berpengaruh terhadap proses clustering penduduk miskin. Hal ini dapat dijadikan pertimbangan bagi pihak pemerintah Kabupaten Bantul untuk mencermati ulang kriteria penghasilan suatu keluarga.

\section{B. Perhitungan Xie Beni}

Nilai Xie Beni index digunakan untuk menentukan jumlah cluster yang paling optimal. Pada tabel 5 dapat dilihat beberapa jumlah data dan jumlah cluster yang digunakan sebagai data uji. Jumlah data yang dipakai adalah 23 (diambil dari data keluarga yang ada di Dukuh Karanggayam), 500, 1000 dan 1313. Jumlah cluster yang dicoba pada masing-masing data yaitu 2, 3, 4, 5, 6 dan 7 . Berdasarkan hasil validasi index dapat dilihat bahwa nilai validasi index pada masing-masing cluster yang diujikan berbeda.

Tabel 5. Hasil Validasi Index Xie Beni

\begin{tabular}{|c|c|c|}
\hline Jumlah Data & Jumlah Cluster & Xie Beni \\
\hline \multirow[t]{6}{*}{23} & 2 & 0.1534 \\
\hline & 3 & 0.1194 \\
\hline & 4 & 0.1042 \\
\hline & 5 & 0.0606 \\
\hline & 6 & 0.1166 \\
\hline & 7 & 0.1329 \\
\hline \multirow[t]{6}{*}{500} & 2 & 0.5895 \\
\hline & 3 & 0.3566 \\
\hline & 4 & 0.1687 \\
\hline & 5 & 0.1569 \\
\hline & 6 & 0.3350 \\
\hline & 7 & 0.4210 \\
\hline \multirow[t]{6}{*}{1000} & 2 & 0.6400 \\
\hline & 3 & 0.3367 \\
\hline & 4 & 0.1683 \\
\hline & 5 & 0.1467 \\
\hline & 6 & 0.3477 \\
\hline & 7 & 0.5675 \\
\hline \multirow[t]{6}{*}{1313} & 2 & 0.6773 \\
\hline & 3 & 0.2385 \\
\hline & 4 & 0.1704 \\
\hline & 5 & 0.1343 \\
\hline & 6 & 0.2509 \\
\hline & 7 & 0.3098 \\
\hline
\end{tabular}

Berdasarkan tabel 5, Nilai Xie Beni pada 23 data paling kecil adalah pada saat jumlah clusternya 5 dengan nilai Xie Beni 0.0606, Nilai Xie Beni pada 500 data paling kecil adalah pada saat jumlah clusternya 5 dengan nilai Xie Beni 0.1569. Nilai Xie Beni pada 1000 data paling kecil adalah pada saat jumlah cluster-nya 5 dengan nilai Xie Beni 0.1467. Nilai Xie Beni pada 1313 data paling kecil adalah pada saat jumlah cluster-nya 5 dengan nilai Xie Beni 0.1343. Berdasarkan data tersebut maka dapat disimpulkan bahwa nilai Xie Beni terkecil diperoleh pada jumlah cluster yang paling banyak dengan jumlah cluster optimal sebanyak 5 .

\section{KESIMPULAN}

Berdasarkan hasil dan pembahasan yang telah dipaparkan sebelumnya maka dapat diambil kesimpulan sebagai berikut:

1. Penggunaan information gain dengan threshold 0.0001 untuk clustering dengan menghilangkan atribut penghasilan memiliki hasil cluster yang sama dengan menggunakan atribut penghasilan.

2. Hasil pengujian terhadap 23, 500, 1000 dan 1313 untuk jumlah cluster 2, 3, 4, 5, 6 dan 7 menunjukkan bahwa nilai dari Xie-Beni Index terkecil adalah 5 dengan nilai 0,1343, sehingga cluster yang paling optimal adalah 5 .

\section{REFERENSI}

[1] Azhagusundari, B. dan Thanamani, A.S. (2013). Feature Selection Based on Information Gain. International Journal of Innovative Technology and Exploring Engineering (IJITEE) ISSN:2278-3075, Volume-2, Issue-2, pp. 18-21.

[2] Chandani, V., Wahono, R.S., dan Purwanto. (2015). Komparasi Algoritma Klasifikasi Machine Learning dan Feature Selection pada Analisis Sentimen Review Film. Journal of Intelligent Systems. Vol.1, No.1, February 2015, pp. 55-59.

[3] Duo, C., Xue, L., dan Du-Wu, C.. (2007). An Adaptive Cluster Validity Index for the Fuzzy C-Means. International Journal of Computer Science and Network Security. Vol. 7, No.2. 146-156.

[4] Purnamasari, S.B., Yasin, H. dan Wuryandari, T. (2014). Pemilihan Cluster optimum pada Fuzzy CMeans (Studi Kasus : Pengelompokan Kabupaten/Kota di provinsi Jawa Trngah Berdasarkan Indikator Indeks Pembangunan Manusia). Jurnal Gaussian, volume 3. Nomor 3. Halaman 491-498.

[5] Sela, E.I. (2015). Penentuan Indikator yang Berperan Pada Identifikasi Kemiskinan Menggunakan Data Mining. Jurnal Riset Daerah Edisi Khusus, hal 16-32.

[6] Redjeki, S., Guntara, M., dan Anggoro, P. (2014). Perancangan Sistem Identifikasi dan Pemetaan Potensi Kemiskinan untuk Optimalisasi Program Kemiskinan. Jurnal Sistem Informasi (JSI). Vol.6, No.2 Oktober 2014. ISSN : 2085-1588. hlm 731-743.

[7] Essra, A., Rahmadani, Safriadi. (2016). Analisis Information Gain Attribute Evaluation untuk Klasifikasi Serangan Intrusi. Jurnal ISD Vol.2 No.2 Juli-Desember. ISSN : 2528-5114. hal 9-14.

[8] Marcelloni, F., (2003). Feature Selection Based on A Modified Fuzzy C-Means Algorithm With Supervision, Information Sciences. 151. pp.201-206.

[9] Sen, A., Foster, J. (1997). On Economic Inequality. Clarendon Paperback. New York: Oxford University Press. 